\title{
ENHANCING RICE BRAN OIL YIELD THROUGH SOLID STATE FERMENTATION PRETREATMENT WITH FUNGI
}

\author{
Y.Yunardi ${ }^{1}{ }^{\text {* }}$, H. Meilina, U. Fathanah ${ }^{1}$, R. Mahadina ${ }^{1}$, A. Rinaldi ${ }^{1}$ \\ and J. Jauharlina ${ }^{2}$ \\ ${ }^{1}$ Department of Chemical Engineering, Universitas Syiah Kuala, Banda Aceh 23111, Indonesia \\ ${ }^{2}$ Faculty of Agriculture, Universitas Syiah Kuala, Banda Aceh 23111, Indonesia \\ *E-mail: yunardi@unsyiah.ac.id
}

\begin{abstract}
Indonesia produces a huge amount of rice bran on an annual basis, but not yet converted into valuable products, such as rice bran oil (RBO). RBO is generally produced by solid-liquid extraction through the contact between rice bran and solvents. However, this method produces a low yield of RBO, ranging from $8-19 \%$. This study was conducted to increase the yield of oil from the bran through solid-state fermentation with fungi, Aspergillus niger and Saccharomyces cerevisiae. The highest bran oil yield extracted from the fermented substrate by Aspergillus niger for five days was $14.20 \%$, while the one fermented by Saccharomyces cerevisiae was $24.15 \%$ at the incubation time of four days, respectively. The quality of rice bran oil treated with Aspergillus niger is close to that of a commercial product. Although quantitatively, the oil obtained from bran fermented by Saccharomyces cerevisiae is much higher, a further refining process is required to produce a clear edible oil. Compared to those of conventional extraction methods, the pretreatment of rice bran by solid-state fermentation increases the oil yield up to three times compared to the control.
\end{abstract}

Keywords: Rice Bran, Yield, Solid Fermentation, Aspergillus niger, Saccharomyces cerevisiae

(c) RASĀYAN. All rights reserved

\section{INTRODUCTION}

Indonesia is one of the largest rice-producing countries in the world, after China and India. Statistical data showed that the area of paddy fields in Indonesia covers up to 8.20 million hectares in $2016^{1}$. With such a vast land, the country has been able to produce around 75.39 million tons of dried grain annually ${ }^{2}$. During rice paddy milling process, around $67-70 \%$ white rice is obtained as the main product, and the remaining are by-products consisting of the husk (18-20\%) and rice bran $(8-10 \%)^{3}$. Based on this composition, it is predicted that Indonesia can produce at a rate of 6.0-7.5 million tons of rice bran on an annual basis. In addition to producing millions of tons of rice, the country is also wasting abundant rice bran.

At present, the bran produced from rice mills in the country is still considered as a waste rather than a resource material for the conversion into various valuable products. In rural communities, a part of rice bran is generally utilized as animal feed and a mixture of natural fertilizers, but most of it is wasted or burned. In contrast to other Asian rice-producing countries, such as Japan, Korea, China, India, Taiwan, and Thailand, a large part of rice bran has been converted into edible oil ${ }^{4}$, called Rice Bran Oil (RBO). In Japan, it is even known as "Heart Oil" due to its cardiac friendly status.

There are three main stages involved in the production of RBO, namely rice bran preparation/stabilization, bran extraction to produce crude RBO, and refining the crude RBO to qualify as an edible oil. After milling, ideally, the rice bran has to be processed as soon as possible for the production of RBO. However, for some reason, such as a long distance from the production plant, the fresh rice bran needs to be stored before transported. Unfortunately, storing rice bran after milling will affect the quality of the bran as the raw material for RBO production. The content of free fatty acids in the bran can increase depending on environmental conditions and storage time. Lipase enzymes tend to hydrolyze the oil content into free fatty acids and glycerol. As a result, the quality of the rice bran is reduced, and if it is used as the raw material for oil extraction, the resulted oil will produce a foul smell and bitter taste due to rancidity ${ }^{5}$. As a Rasayan J. Chem., 13(3), 1537-1543(2020) http://dx.doi.org/10.31788/ RJC.2020.1335706

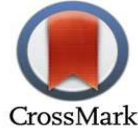


RASĀYAN J. Chem.

Vol. 13 | No. 3 |1537-1543| July - September | 2020

consequence, limiting the activity of the lipase enzyme in the bran is of prime importance to allow storing the bran for a longer period. Several approaches have been proposed as a method to slow down or inactivate the lipase enzyme in the bran, such as drying in the sun, contact with hot air and steam, ${ }^{6-8}$ microwave and infrared treatments ${ }^{9,10}$ and chemical treatment. ${ }^{11}$ Among those methods, microwave treatment and dry heating are the most effective ways of stabilizing the rice bran. ${ }^{10}$

Several processes have been introduced to produce oil from rice bran, including solvent extraction, mechanical pressing, supercritical and subcritical extraction, enzymatic-assisted-aqueous extraction, and ultrasound-assisted extraction. However, solvent extraction using hexane has been the most popular way of producing rice bran oil commercially. In this process, fresh or stabilized rice bran is mixed with hexane at a temperature of $20{ }^{\circ} \mathrm{C}$ to produce a rice bran crude oil. Separation of the solvent from the crude oil is achieved by evaporating the mixture. ${ }^{12}$ The resulted crude RBO has to go through another refining process to get a refined RBO, which meets the standard for edible oil grade. ${ }^{13}$ The current problem faced with the solvent extraction for the isolation of oil from the bran is low oil yield, between 16-19\% of each $\mathrm{kg}$ bran feed. ${ }^{14,15}$ Although different methods for the improvement of oil yield from the rice bran have been proposed, the solvent extraction process is still the most popular used method in the rice bran oil industry. ${ }^{12,16}$ Supercritical fluid extraction (SFE) has been proposed for the separation of oil from the rice bran ${ }^{17}$. The SFE has been claimed to be a prospective future process for the manufacture of ultra-pure bran oil free from toxic residues, allowing direct use of oil without the need for refining. Although the method is capable of producing high-quality oil, its yields are comparable to those obtained using the solvent extraction. Its implementation for the large scale production in the developing country is still limited by high energy requirement as it operates at very high pressure, safety issues, and high capital cost for equipment. If the solvent extraction is still considered as the most practical method for commercial production of rice bran oil at present, hence there should be a particular treatment on the bran before the extraction process to improve the oil yield. Without any preliminary treatment on the raw material, it would be very difficult to have a higher yield of bran oil.

Various preliminary treatments on the bran aiming at increasing the yield with the aid of ultrasound ${ }^{18,19}$, microwave ${ }^{20,21}$ and enzyme $e^{22,23}$ have been reported. Utilization of ultrasound-assisted aqueous extraction of edible oil from rice bran has not yet been able to produce the oil yield higher than that of hexane soxhlet extraction. Khoei and Chekin ${ }^{18}$ compared the rice bran oil extractability (yield) resulted from the use of ultrasound-assisted aqueous and soxhlet extractions and found out that the yield of the former was around $19 \%$ while the latter $24 \%$. A similar yield using the ultrasound-assisted method was also reported by Djaeni and Listyadevi. ${ }^{19}$ An advanced method of improving the oil yield from rice bran, such as microwaveassisted extraction, does not always produce better results compared to the conventional solvent extraction $^{21}$. However, enzyme-assisted rice bran oil extraction provides promising results as it can produce a yield similar produced by the soxhlet extraction.

Solid-state fermentation by fungi or other types of microorganisms has been a long-time part of the Indonesian culture for the production of local traditional fermented food such as tempeh ${ }^{24}$ and tape. ${ }^{25} \mathrm{Also}$, such fermentation has been traditionally utilized for enhancing oil recovery from shredded coconut meat, particularly in the Province of Aceh, Indonesia. ${ }^{26}$ However, to the authors' knowledge, there no publication has been reported regarding the use of fungi through solid-state fermentation in an attempt to improve the yield of rice bran oil. The purpose of the present study was to compare the effect of different fungi species, Aspergillus niger, and Saccharomyces cerevisiae through solid-state fermentation pre-treatment of rice bran on the oil yield.

\section{EXPERIMENTAL}

\section{Materials}

Stock culture of Aspergillus niger was purchased from Microbiology Laboratory, School of Life Sciences and Technology, Bandung Institute of Technology, Bandung, Indonesia. Saccharomyces cerevisiae culture was obtained from Bioprocess Laboratory, Chemical Engineering Department, Syiah Kuala University, Banda Aceh, Indonesia. All chemicals used in the current study were of analytical grade and obtained from Sigma-Aldrich. Fresh rice bran was collected from a rice mill in Lambaro, Aceh Besar, Indonesia. Upon arrival in the laboratory, it was directly sieved to pass a screen of 40 mesh and immediately used for the solid-state fermentation experiment after it was autoclaved. 
RASĀYAN J. Chem.

Vol. 13 | No. 3 |1537-1543| July - September | 2020

\section{Inoculum Preparation}

Both stock cultures of Aspergillus niger and Saccharomyces cerevisiae were multiplied in solid media of potato dextrose agar (PDA). After growing, the culture from the solid media was inoculated in the liquid medium containing glucose $(20 \mathrm{~g} / \mathrm{L}), \mathrm{KH}_{2} \mathrm{PO}_{4}(3 \mathrm{~g} / \mathrm{L})$, and $\mathrm{MgSO} 4(1.5 \mathrm{~g} / \mathrm{L})$ and incubated at a temperature of $30^{\circ} \mathrm{C}$ in orbital shaker set at $120 \mathrm{rpm}$ for one day, but extended up to 7 days for the growth of microorganism study. Similar treatment applied to Saccharomyces cerevisiae; however, the inoculation was done in the yeast-peptone-glucose (YPG) liquid medium consisting of glucose (20 g/L), peptone (10 $\mathrm{g} / \mathrm{L})$ and yeast extract $(20 \mathrm{~g} / \mathrm{L})$.

\section{The Solid-state Fermentation Procedure}

A $100 \mathrm{~g}$ autoclaved rice bran sample was taken into $250 \mathrm{~mL}$ flask and added with $25 \mathrm{~mL}$ respective inoculant. To keep enough moisture in the substrate, $40 \mathrm{~mL}$ of distilled water was added to the flask. The mixture of bran and inoculant was fermented for 1, 2, 3, 4, 5, 6, and 7 days at a temperature of $30^{\circ} \mathrm{C}$. Every 24 hours, the mixture was stirred bran to maintain the homogeneity of the solid substrate. Fermented bran samples are removed from the incubator and dried in the oven before the extraction. A controlled experiment was also performed by which the rice bran was treated without fermented with microorganisms.

\section{Bran Oil Extraction and Refining}

The extraction operation was started by preparing $30 \mathrm{~g}$ dried fermented rice bran and filled in a thimble and placed in a soxhlet extraction equipment connected to the round bottom flask. A $300 \mathrm{~mL}$-hexane was used as a solvent to extract the oil. The extraction process was carried out for 90 minutes. After the end of the cycle, the n-hexane was recovered from oil using a rotary evaporator. A simple refining process was performed by adding $5 \mathrm{~g}$ activated bentonite into a flask containing $30 \mathrm{~mL}$ crude rice bran oil, and the mixture was stirred at $100 \mathrm{rpm}$ and $40^{\circ} \mathrm{C}$ for 20 minutes. The percentage of rice bran oil yield can be calculated following Eq.-1.

\section{Analytical Method}

$$
\% \text { Rice Bran Oil Yield }=\frac{\text { Weight of Oil Extracted }}{\text { Weight of Initial Rice Bran }} \times 100 \%
$$

Physical and chemical characteristics of the resulted rice bran oil, including density, viscosity, color, refractive index, water content, free fatty acid, peroxide, iodine, and saponification values were determined in accordance to Codex Alimentarius ${ }^{27}$, except for the peroxide value which followed the Indonesian National Standard ${ }^{28}$ for edible oil.

\section{Fungal Growth Study in the Liquid Medium}

\section{RESULTS AND DISCUSSION}

Figure-1 presented the result of the microbial growth study of Aspergillus niger and Saccharomyces cerevisiae in the respective liquid medium for 7 days. In this study, the cell growth was measured indirectly using dry weight method, instead of the number of cells. The reason behind this selection was because the method is easy and provides rapid results. Although the method is not very accurate, as it cannot distinguish between live and dead cells, the selected method is deemed sufficient for the current study to investigate the impact of fungal pre-treatment on the rice bran towards the oil yield.

Generally, microorganisms will experience a lag phase (acclimatization stage) during the initial incubation period. However, the lag phase of the two microorganisms is not seen in Fig.-1. This is most likely due to the measurement of cell mass was taken at a 24-hour interval. Consequently, the lag phase behavior, which most probably occurred during the first few hours, is not detected. However, from Fig.-1, it is evident that both microorganisms are equally able to adapt quickly to the liquid medium environment, as indicated by an exponential increase in cell mass from the beginning until the end of the 24 hours. During the incubation period, Aspergillus niger experienced quite rapid growth, reaching its peak growth within 24 hours. Its growth then declined up to the end of the incubation period. In contrast, the growth rate of Saccharomyces cerevisiae continued to increase with increasing incubation time, which might be due to richer nutrients in its liquid medium in comparison to that of Aspergillus niger. 
RASĀYAN J. Chem.

Vol. 13 | No. 3 |1537-1543| July - September | 2020

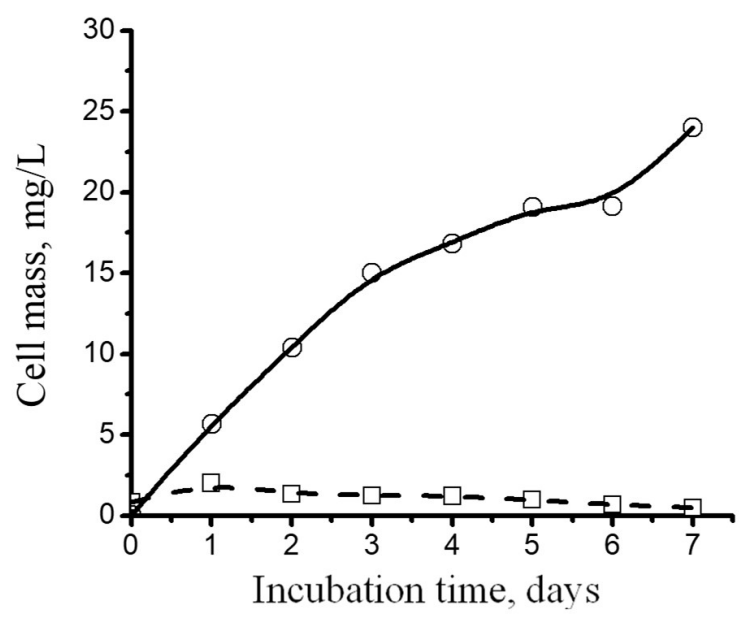

Fig.-1: Fungal Growth in the Liquid Medium, Solid Line: Saccharomyces cerevisiae, Dashed Line: Aspergillus

\section{Rice Bran Oil Yield} niger.

Figure-2 presented a comparison of extracted oil yield from rice bran treated with solid-state fermentation and without fermentation. The solid line with $\circ$ symbol represented the rice bran oil yield experiencing the fermentation with Saccharomyces cerevisiae, while a dashed line with $\square$ the symbol was the oil yield resulted from the extraction of rice bran having fermented with Aspergillus niger and the dotted line with $\Delta$ was the yield of oil extracted bran rice without any fermentation treatment (control experiment). The rice bran of the control experiment was isolated for its oil through hexane solvent extraction.

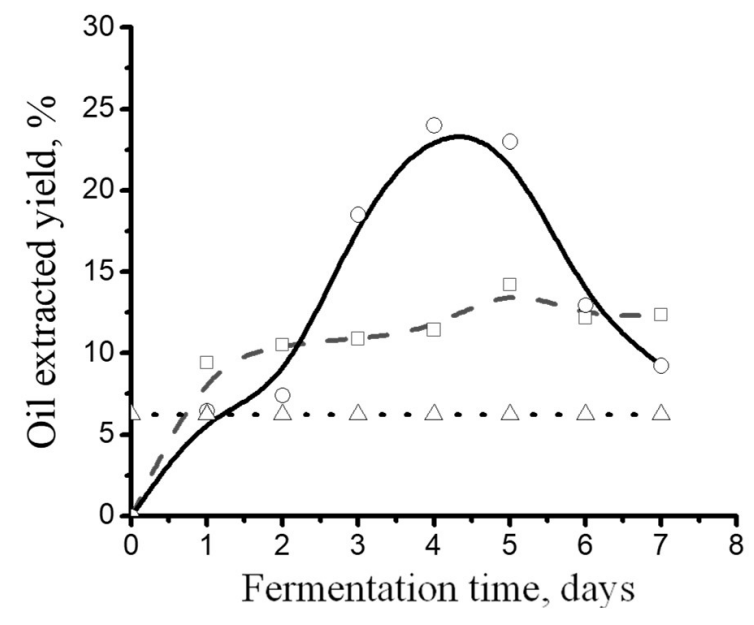

Fig.-2: Comparison of Oil from Rice Bran after Solid-state Fermentation with Saccharomyces cerevisiae (Solid Line) and Aspergillus niger (Dashed Line), and without Fermentation (Dotted Line).

The rice bran oil produced through the control experiment in this study is quite low, around $6.25 \%$ out of $100 \mathrm{~g}$ rice bran samples. Such low yield could be due to short contact time between the solvent and the rice bran. In this study, the contact time for the solvent extraction was set up at 90 minutes, while other studies $^{29,30}$ showed that a contact time between 6 and 9 hours during the solvent extraction could yield rice bran oil between 8.5 and $12 \%$. Nonetheless, the current oil yield from the control experiment will be used as a reference for the calculation of improvement in yield by solid-state fermentation.

Inspection of oil yield resulted from the rice bran that underwent solid-state fermentation by Saccharomyces cerevisiae; from Fig.-2, it is clear that the oil yield is increasing as the increasing fermentation time and achieving its peak when the fermentation time reached four days. At this point, the solvent extraction of 
RASĀYAN J. Chem.

Vol. 13 | No. 3 |1537-1543| July - September | 2020

fermented rice bran by Saccharomyces cerevisiae could produce oil with the highest yield of $24.15 \%$. Comparing to the oil yield resulted from the control experiment, it is a very significant improvement, reaching around a $286 \%$ increase. The promising result on oil yield demonstrated from rice bran fermented by Saccharomyces cerevisiae is not arose by the one fermented by Aspergillus niger. Although the application of Aspergillus niger in the solid-state fermentation of rice bran produced an increase in oil extraction yield in comparison to the yield of the control experiment, the increase is not significant compared to the one that resulted in the use of Saccharomyces cerevisiae in the solid-state fermentation of the rice bran. Although there is a significant increase in comparison to one of the control experiments, the oil yield resulted from Aspergillus niger was slightly better than the one produced by solvent extraction alone. In a conventional extraction study, using hexane as the solvent and contact time of six hours, the rice bran could produce an oil yield of $11.89 \%^{29}$ and with five hours of contact, time gave an oil yield of $8.49 \%{ }^{30}$, while solid-state fermentation with Aspergillus niger produced rice bran oil yield of $14.20 \%$ after five days of fermentation. In the present study, the microorganism growth in the solid-state was not measured, but it should be suspected that the growth Aspergillus niger in the rice bran is much lower than that of Saccharomyces cerevisiae, following the growth pattern in the liquid state. Less cell mass of Aspergillus niger grown in the solid-state of rice bran requires further investigation, as this was not the case when Aspergillus niger was grown on the soybean ${ }^{31}$. However, it should be noted that enzymes produced by both microorganisms did assist in the increase of oil release from the rice bran, particularly protease enzyme produced by the activity of Saccharomyces cerevisiae.

\section{Rice Bran Oil Quality}

Table-1 presented the quality of rice bran oils obtained from pre-treated by solid-state fermentation by Saccharomyces cerevisiae and Aspergillus niger. Although several parameters govern the quality of the rice bran oil, only important parameters were measured in this study. For comparison, the Indonesian standard for edible oil ${ }^{28}$ and Codex Alimentarius ${ }^{27}$ are presented as well. Inspection of the moisture content in rice bran oils resulted from pretreatment with Aspergillus niger and Saccharomyces cerevisiae; it is much higher compared to the one stipulated in the Indonesian standard for edible oil. The formers are $1.094 \%$ and $3.433 \%$, respectively, while the latter is $0.15 \%$. A similar case is also seen in the color in which the Indonesian standard requires the color should be clear up to yellow, while oils resulted from this study gave darker color. On this basis, rice bran oils resulted from this study have not yet fulfilled the standard for edible oil. However, comparing the quality of oils resulted from the present study with the quality crude rice bran oil proposed by Codex Alimentarius ${ }^{27}$, all values for density, refractive index, iodine value, and saponification value are in the recommended range. These results indicate that oils produced from rice bran pre-treated with microorganisms through solid-state fermentation are categorized as crude rice bran oil. Further treatment through the refining process is required for such oil to be used as edible oil.

Table-1: Quality Comparison of Rice Bran Oil pretreated with Fermentation and Available Standards

\begin{tabular}{|c|c|c|c|c|c|c|c|c|c|}
\hline \multirow{2}{*}{$\begin{array}{l}\text { Rice Bran Oil } \\
\text { resulted from } \\
\text { Solid-state } \\
\text { Fermentation } \\
\text { by }\end{array}$} & \multicolumn{9}{|c|}{ Quality } \\
\hline & $\begin{array}{l}\text { Density } \\
(\mathrm{gr} / \mathrm{mL})\end{array}$ & $\begin{array}{l}\text { Viscosity } \\
(\mathrm{kg} / \mathrm{m} . \mathrm{s})\end{array}$ & $\begin{array}{c}\text { Moisture } \\
(\%)\end{array}$ & $\begin{array}{l}\text { FFA } \\
(\%)\end{array}$ & $\begin{array}{l}\text { Refract- } \\
\text { ive } \\
\text { Index }\end{array}$ & Color & $\begin{array}{c}\text { Peroxide } \\
\text { value } \\
\text { (meq } \\
\mathrm{O}_{2} / \mathrm{kg} \text { ) } \\
\end{array}$ & $\begin{array}{l}\text { Iodine } \\
\text { Value }\end{array}$ & $\begin{array}{c}\text { Saponifi- } \\
\text { cation } \\
\text { Value }\end{array}$ \\
\hline $\begin{array}{c}\text { Aspergillus } \\
\text { niger }\end{array}$ & 0.922 & 8.906 & 1.094 & 36.096 & 1.460 & Yellow & 5 & 101.52 & 193.324 \\
\hline $\begin{array}{c}\text { Saccharomyces } \\
\text { cerevisiae }\end{array}$ & 0.926 & 9.793 & 3.433 & 51.465 & 1.458 & Brown & 5 & 101.52 & 198.011 \\
\hline $\begin{array}{c}\text { Indonesian } \\
\text { edible oil } \\
\text { standard } \\
(\text { SNI-3471- } \\
2013)^{28}\end{array}$ & - & - & 0.15 & - & - & $\begin{array}{l}\text { Clear } \\
\text { up to } \\
\text { yellow }\end{array}$ & Max. 10 & - & - \\
\hline $\begin{array}{c}\text { Codex } \\
\text { Alimentarius }^{27}\end{array}$ & $\begin{array}{c}0.910- \\
0.929\end{array}$ & & & & $\begin{array}{l}1.460- \\
1.470\end{array}$ & & & $\begin{array}{l}90- \\
115\end{array}$ & 180-199 \\
\hline
\end{tabular}


RASĀYAN $J$. Chem.

Vol. 13 | No. 3 |1537-1543| July - September | 2020

\section{CONCLUSION}

The results of the current study lead to the conclusion that the application of solid-state fermentation as a pretreatment on the rice bran significantly improves the oil yield. The use of Saccharomyces cerevisiae for the solid-state fermentation of rice bran and also probably for other edible oil plant is recommended as it can assist to considerably increase the oil yield nearly threefold compared to the one resulted from the use of solvent extraction alone. However, about the quality of rice bran oil produced with the aid of solid-state fermentation, further treatment through the refining process is still required to produce a clear edible oil.

\section{ACKNOWLEDGMENT}

The authors would like to express their gratitude for the financial support provided by the Directorate of Research and Community Extension, Ministry of Research, Technology and Higher Education of the Republic of Indonesia through Contract No: 215/SP2H/LT/DPRM/2019 dated March 8, 2019.

\section{REFERENCES}

1. https://www.bps.go.id/dynamictable/2015/09/10/895/luas-lahan-sawah-menurut-provinsi-ha-2003 2015.html

2. https://www.bps.go.id/dynamictable/2015/09/09/865/produksi-padi-menurut-provinsi-ton-19932015.html

3. K. Gul, B. Yousuf, A. K. Singh, P. Singh, and A. A. Wani, Bioactive Carbohydrates and Dietary Fibre, 6, 1(2015), DOI: 10.1016/j.bcdf.2015.06.002

4. G.A. Nayik, I. Majid, A. Gull and K. Muzaffar, Rice Research. 3, 4(2015), DOI:10.4172/23754338.1000151

5. R. Sharma, T. Srivastava and D.C. Saxena, International Journal of Engineering Research and Applications, 5,107 (2015),

6. B.M. Amarasinghe, W.P.K., Kumarasiri, M.P.M., and N.C. Gangodavilage, Food and Bioproducts Processing, 87,108(2009), DOI:10.1016/j.fbp.2008.08.002

7. H. R Sharma, G. S. Chauhan, and K Agrawal, International Journal of Food Properties, 7, 603(2004), DOI: $10.1081 / \mathrm{JFP}-200033047$

8. N. Yilmaz, Food Chemistry, 190, 179(2016), DOI:10.1016/j.foodchem.2015.05.094

9. S.S. Patil, A. Kar, and D. Mohapatra, Food and Bioproducts Processing, 99, 204(2016), DOI: $10.1016 /$ j.fbp.2016.05.002

10. M. Patel and S.N. Naik, Journal of Scientific and Industrial Research, 63, 569(2004)

11. J. V. Prabhakar and K. V. L. Venkatesh, Chemistry and Materials Science, 63, 644(1986), DOI: $10.1007 / B F 02638229$

12. D. Spark, R. Hernandez, M. Zappi, D. Blackwell and T. Fleming, Journal of the American Oil Chemists' Society, 83, 10(2006), DOI: 10.1007/s11746-006-5042-x

13. W. Kong, Q. Kang, W. Feng and T. Tan, Chemical Engineering Research and Design, 104, 1(2015), DOI: 10.1016/j.cherd.2015.06.001

14. A. Proctor and D.J. Bowen, Journal of the American Oil Chemists' Society, 73, 811(1996), DOI: $10.1007 / \mathrm{BF} 02517960$

15. N.S. Mohd Daud, D.N.A. Zaidel, K.S Lai, N. Khairuddin, Y.M Mohd Jusoh and I.I. Muhamad, Arabian Journal for Science and Engineering, 43, 6237(2018), DOI:10.1007/s13369-018-3438-1

16. U. Garba, R. Singanusong, S. Jiamyangyuen, and T Thongsook. In Proceedings of The 4th International Conference on Rice Bran Oil, Bangkok, Thailand, pp. 1-12 (2017).

17. K. Tomita, S. Machmudah, Wahyudiono, R. Fukuzato, A. T. Quitain, M. Sasaki, M. Goto and H. Kanda, Separation and Purification Technology, 125, 319(2014), DOI:10.1016/j.seppur.2014.02.008

18. M. Khoei and F. Chekin, Food Chemistry, 194, 503(2016), DOI:10.1016/j.foodchem.2015.08.068

19. M. Djaeni and Y. L. Listyadevi, Journal of Physics: Conference Series, 1295, 012027(2019), DOI: 10.1088/1742-6596/1295/1/012027

20. R. Pandey and S.L. Shrivastava, Journal of Food Engineering, 218, 106(2018), DOI: 10.1016/j.jfoodeng.2017.09.009

21. H. S. Shukla and A. Pratap, Journal of Oleo Science. 66, 973(2017), DOI:10.5650/jos.ess17067 1542 
RASĀYAN J. Chem.

Vol. 13 | No. 3 |1537-1543| July - September | 2020

22. F. S. Taha, R. M. Mourad, S. S. Mohamed and A I. Hashem, American Journal of Food Technology, 7, 452(2012), DOI:10.3923/ajft.2012.452.469

23. A, Sharma, S.K. Khare, M.N. Gupta., Journal of the American Oil Chemists' Society, 78, 949 2001), DOI: $10.1007 / \mathrm{s} 11746-001-0369-\mathrm{X}$

24. Sutardi and K.A. Buckle., International Journal Food Microbiology. 6, 67(1988), DOI:10.1016/01681605(88)90086-4

25. M.M. Ardhana and G. H. Fleet., International Journal Food Microbiology. 9, 157(1989), DOI: $10.1016 / 0168-1605(89) 90086-x$

26. N. Earlia, Muslem, R. Suhendra, M. Amin, C. R. S. Prakoeswa, Khairan and Rinaldi Idroes, The Scientific World Journal, 2019, 1(2019), DOI:10.1155/2019/8605743

27. Codex Alimentarius, Codex Standard for Named Vegetable Oils, Codex Stan., 210-1999, 11 (2015)

28. Badan Standarisasi Nasional, SNI 01-3741-2013, Badan Standarisasi Nasional, p. 7, 9 (2013)

29. A. Budiyanto, M. Hadipernata and S.I. Kailaku. In Proceedings International Conference on Agricultural Postharvest Handling, and Processing (ICAPHP), Jakarta, Indonesia, pp. 739-746 (2013)

30. F. Mas'ud and Pabbenteng, Journal INTEK, 3, 82 (2016), DOI:10.31963/intek.v3i2.56

31. X.Niu, S. Qiu, Y. Wu, J. Yuan dan Y. Xu. Frontiers of Chemical Science and Engineering, 5, 122 (2011), DOI: $10.1007 / \mathrm{s} 11705-010-0533-6$.

[RJC-5706/2020] 